\title{
Intermédialités
}

Histoire et théorie des arts, des lettres et des techniques

Intermediality

History and Theory of the Arts, Literature and Technologies

\section{The Politics of Intermediality in African Theatre Contexts}

\section{Catherine Makhumula}

Numéro 30-31, automne 2017, printemps 2018

cartographier (l'intermédialité)

mapping (intermediality)

URI : https://id.erudit.org/iderudit/1049950ar

DOI : https://doi.org/10.7202/1049950ar

Aller au sommaire du numéro

Éditeur(s)

Revue intermédialités (Presses de l’Université de Montréal)

ISSN

1920-3136 (numérique)

Découvrir la revue

Citer cet article

Makhumula, C. (2017). The Politics of Intermediality in African Theatre

Contexts. Intermédialités / Intermediality, (30-31).

https://doi.org/10.7202/1049950ar

\section{Résumé de l'article}

Dans cet article, nous discutons de la politique de l'intermédialité saisie dans le contexte du théâtre africain. Notre hypothèse est que l'étude de l'intermédialité est de nature inévitablement contextuelle en étant fortement liée aux sphères socio-politique et économique. Dans son article « The Politics of Intermediality ", Jean Schröter explore les liens entre l'intermédialité et les facteurs idéologiques / politico-économiques, soutenant que les questions relatives à l'intermédialité ne sont jamais exclusivement théoriques ou esthétiques, mais au contraire chargées de connotations politiques. S'appuyant sur ce dernier, notre approche se focalise sur la façon dont une culture développe sa compréhension propre des interactions et des différences entre les médias, à un moment historique donné. En utilisant des exemples provenant de la région sud du continent africain, cet article parcourt des théories divergentes sur le théâtre en Afrique, afin de mieux comprendre les relations entre les médias, telles que le discours théorique propre à cette région les conceptualise. 


\title{
The Politics of Intermediality in African Theatre Contexts
}

\author{
Catherine Makhumula
}

\section{INTRODUCTION}

nlike the overall enthusiasm with the concept of intermediality in the West, theatre scholars writing from various African contexts have been less enthusiastic about discussing the interrelations among media as "intermedial." Their indifference is apparent in their critique of the narrowly technocentric interpretation of media ${ }^{\mathrm{I}}$ as well as in their limited application of the concept in their scholarship. ${ }^{2}$ However, scholars on African theatre have noted that contemporary artistic practice in some theatre contexts has been much more experimental in exploring the interrelations among media. ${ }^{3}$ According to them, contemporary African theatre artists are increasingly incorporating new media technologies, expressive means, and aesthetic concepts from other media in their performances, in ways that surpass medium specificity. Even though theatre scholars such as Ngozi Udengwu, Ofonime

I An example of such critique is found in David Kerr, "Introduction by David Kerr," in David Kerr (ed.), African Theatre 1o: Media ES Performance, Suffolk and New York, James Currey, 20II, p. xiv. Kerr's anthology includes contributions from Eastern Africa (Tanzania and Uganda), Southern Africa (South Africa, Zimbabwe, and Botswana), and West Africa (Nigeria). He acknowledges that missing contributions about Francophone or North African theatre is an important methodological gap in his anthology. Despite this, he still makes conclusions about African theatre, media, and performance.

${ }^{2}$ This is my observation after conducting an extensive literature search for a $\mathrm{PhD}$ study on intermediality in two Southern African nations, from 2014 to 2017.

${ }^{3}$ Also an example here is Kerr, 2olI, p. xviii. His anthology is one of the first book-length works that discusses the impact of new media and the use of multimedia technologies on live and recorded performance in Africa. My own $\mathrm{PhD}$ work, using examples from Malawi and South Africa, made the same observation. See Catherine Makhumula, Within between: An Investigation on Intermediality in the Malawian and South African Theatre Context, doctoral dissertation, Stellenbosch, Stellenbosch University, 2017. 
Inyang, Izuu Nwanko, and Julius Adeoye Rantimi have emphatically critiqued theatre's loss of a dominant status and its changing functions in society, due to the ubiquity of new media in the present age, ${ }^{4}$ there exists little literature in African theatre studies that explores the phenomenon of media interrelations or that reconsiders theatre and other media as intermedial phenomena.

In this article, I discuss media interrelations as conceptualized within the theoretical discourses of African theatre contexts. I argue that the absence of the term "intermediality" in these contexts should not be viewed as evidence of its absence both in theory and in practice. I therefore explore a tacit intermedial research axis and examine how intermediality exists within African theatre contexts before posing critical questions regarding the use of the concept of intermediality itself. I borrow the term "intermedial research axis" from Jürgen E. Müllers who uses it to refer to the writing practices and the history of intermedial processes. Müller argues that a historiography of intermedia processes would have to unfold in a specific social and historical context. In my usage of the term, I seek to demonstrate that the use of the concept "intermediality," the existence of particular phenomena-what one would call "intermedial phenomena" - and the writing practices around them, which Müller calls "the intermedial research axis," does not always exist congruently. Just like Jens Schröter, ${ }^{6}$ I argue that questions concerning media interrelations in African theatre theoretical discourses are not purely theoretical or aesthetic questions; rather, they are laden with political connotations.

4 The list cited here includes Nigerian theatre scholars who critique the impact of film on the genre of live theatre performance in Nigeria. See Ngozi Udengwu, "Theatre-OnDemand: Stella Oyedepo - Theatrical Megastar of the Twenty-First Century,” in Kenechukwu Igweonu(ed.), Trends in Twenty-first Century African Theatre and Performance, Amsterdam, Rodopi, 20II, p. 342; Ofonime Inyang, "Sustaining the African Theatre in a Digital Age," unpublished manuscript, Academia.edu, 20o8, p. 2; Izuu Nwanko, "On the Difference of the Same: Theatre, Performance and the Tortuous Path of a Nation's Development," Nigerian Theatre Journal, vol. Io, no. I, 20I0, p. 34; Julius Adeoye Rantimi, "Nigerian Theatre Arts Curriculum and Events Management," Nigerian Theatre Journal, vol. IO, no. I, 20IO, p. 229.

5 Jürgen E. Müller, "Intermediality and Media Historiography in the Digital Era," Acta Universitatis Sapientiae: Film and Media Studies, vol. 2, 2010, p. 15-38.

${ }^{6}$ Jens Schröter, "The Politics of Intermediality," Scientific Journal of Sapientia, vol. 2, 2010, p. 107-I24. 
Before I go any further, it is imperative to clarify that my analysis of "African theatre contexts" is rooted in Anglophone theatre in Africa. ${ }^{7}$ This is because there seems to be a difference in the writing practices and attitudes towards intermediality between English-speaking and French-speaking Africa. There are certainly more publications on intermediality produced in Francophone Africa ${ }^{8}$ than in

7 My examples in this article are from Malawi and South Africa and my research interest is in theatre in the Southern African region. However, the scholars I critique in this article write from a number of African contexts such as Nigeria (Kenechukwu Igweonu, Ngozi Udengwu, Ofonime Inyang, Izuu Nwanko, Julius Adeoye Rantimi); Malawi (Steve Chimombo); South Africa (H. I. E. Dhlomo, Gaerin Hauptfleisch, Moratiwa Molema, Dominik Lukasz Pater), and Kenya (Chris Odhiambo, Ngũgĩ Wa Thiong'o). More importantly, as I note in the article, most of the work cited here (including my own previous work) tends to generalize "African theatre" and make conclusions about theatre on the entire continent, despite the fact that scholarship is produced within a specific geographical context; this is also the case when scholarly work is part of an anthology whose contents are representative of a number of African countries (for example, David Kerr, Kenechukwu Igweonu, Susan Arndt, Eckhard Breitinger and Spitczok von Brisinski). The article provides a critical look at these generalizations.

${ }^{8}$ The list below represents a sample of publications on intermediality from Francophone Africa and it is not meant to be exhaustive list: François Guiyoba, "L'effet de vie à la croisée des arts : vers une théorie esthétique unitaire?" in François Guiyoba (ed.), Entrelacs des arts et effet de vie, coll. "Beaux-arts Littérature," Paris, L’Harmattan, 20I2; Philip Amangoua Atcha, "Les tissages médiatiques dans le roman africain francophone," in Philip Amangoua Atcha, Roger Tro Deho, Adama Coulibaly (eds.), Médias et littérature - Formes pratiques et postures, Paris, L'Harmattan, 2014, p. I53-169; Philip Amangoua Atcha, "Formes d'expression intermédiales et renouvellement du roman africain francophone," in Susan Gehrmann, Flora VeitWild(eds.), Conventions and Conversions: Generic innovation in African Literature/Innovations génériques dans les littératures africaines, Trier, Germany, WVT, 2012, p. 4I-54; Philip Amangoua Atcha, "Pratique intermédiale et création romanesque chez Williams Sassine," En-Quête, vol. 2I, 2009, p. 49-65; Robert Fotsing Mangoua (ed.), Écritures camerounaises francophones et intermédialité, Yaoundé, Cameroon, Éditions Ifrikiya, coll. "Interlignes," 20I2; Robert Fotsing Mangoua, "De l'intermédialité comme approche féconde du texte francophone," Synergies Afrique de Grands-Lacs, no. 3, 20I4, p.I27-I4I; Susanne Gehrmann, “Au-delà du Jazz. L'intermédialité dans l'écriture de Kangni Alem,” in Susanne Gehrmann, Dotsé Yigbe (eds.), Créativité intermédiatique au Togo et dans la diaspora togolaise, vol. 9, Münster, Germany, LIT Verlag Münster, 20I5, p. 85; Philip Amangoua Atcha, "L'intermédialité littéraire dans le roman camerounais. L'exemple de 'La mémoire amputée' de Werewere Liking," Robert Fotsing Mangoua (ed.), Écritures camerounaises francophones et intermédialité, Yaoundé, Cameroon, Éditions Ifrikiya, coll. "Interlignes”, 2012, p. 75-92; Alain Cyr Pangop, "Théâtre tchadien et intermédialité. Corps et voix : paroles rhizomes de Koulsy Lamko," in Mosaïques $n^{\circ} 3$-La littérature sabélienne $d u$ bassin du lac Tchad: voix, langages et poétiques, Paris, Éditions des Archives Contemporaines, 2015, p. 65; Alain Cyr Pangop, "Remédiation de l'oralité et transferts médiatiques dans les cultures populaires au Cameroun," 
Anglophone Africa. 9 Unfortunately, because of the language barrier, my knowledge of the Francophone African theatre contexts is severely limited.

It is also worthwhile stating, at this point in the article, that my analysis of "African theatre theory" will mostly take the form of a critique of the tendency by scholars writing from various African contexts to generalize their findings and extend them to all of Africa, without paying attention to the specific historical, political, cultural, and artistic contexts in many discussions on African theatre. Due to this tendency to generalize, these scholars and their work fail to account for the nuanced historiography of intermedia processes as it unfolds in specific social and historical contexts.

I undertake a conceptual unpacking of the concept of intermediality in order to explore a contextual understanding of it. I begin this task with an exploration of "politics" to clarify its usage in this article. I then discuss intermediality to explore the established as well as emerging discourses around the concept, both in general and in its usage in theatre specifically, in the West and in Africa. Finally, I contextualize intermediality through specific examples of African theatre. While this article is not intended to build an elaborate theory of intermediality for the entire continent of

Intermédialité: Histoire et théorie des arts, des lettres et des techniques, no. 4, "Re-dire," 2009, http://cri.histart.umontreal.ca/cri/fr/intermedialites/interface/numeros.html (accessed 27 March 2018).

9 The list below represents a sample of publications on intermediality from Anglophone Africa. It includes most articles I could find using the search term "intermediality." The first four are from the visual arts signifying a more receptive attitude in that field towards the concept of intermediality: Nura Ibrahim, "Intermediality of Images: A Semiotic Analysis of the 'Occupy Nigeria Protest' Images on Social Media," Journal of African Media Studies, vol. 9, no. I, 2017, p. 33-48; Annekie Joubert, "Memory Embroidered: Craft Art as Intermedial Space of Expression," Stichproben, Wiener Zeitschrift fur kritische Afrikastudien/Vienna Journal of African Studies, vol. 17, no. 9, 2009, p. 97-I26; Till Förster, "Layers of Awareness Intermediality and Practices of Visual Arts in Northern Côte D'Ivoire," African Arts, vol. 38 , no. 4, 2005, p. 32-93; Gwyneth Miller, Modelling an Innovative Approach to Intermediality within Visual Art Practice in South Africa, doctoral dissertation, Pretoria, University of South Africa, 2016; Sanjin Muftić, "Bricolage: Re-discovering History through Intermediality and Performance," Research in Drama Education: The Journal of Applied Theatre and Performance, vol. 21, no. 3, 2016, p. 367-372; Fetson Kalua, "Intermediality: A Paradigm for African Identity in the Twenty-First Century," Journal of Literary Studies, vol. 33, no. I, 2017, p. 24-4I. The last entry uses a different conceptualization of "intermediality" to the one expounded in this article. 
Africa, it seeks to begin to map out an intermedial research axis based on an exploration of intermediality in selected contexts. It is my hope that this contextual undertaking will add valuable insights to the ever-expanding field of intermedial studies.

\section{WHAT IS POLITICS ANYWAY?}

According to the Oxford English Dictionary, "o the word "politics" is etymologically derived from the Middle French words politiques and polliticques, which mean either "public affairs" or "government," or from the ancient Greek word $\tau \dot{\alpha} \pi 0 \lambda ı \tau \iota k \dot{\alpha}$, which means "public matters" or "civic affairs." These definitions are similar to the modern-day popular usage of politics as "the theory or practice of government or administration." politics means "the assumptions or principles relating to or underlying any activity, theory, or attitude, especially when concerned with questions of power and status in a society." ${ }^{2}$ This definition is the most relevant to this article.

Jens Schröter uses this conceptualization of "politics of...” in his attempt to highlight the intricate link between the developments in the arts world and the prevailing politico-economic and ideological conditions in a given time and context. Using this understanding of politics, Schröter analyzes the principles underlying the conceptualization of intermediality as it relates to questions of power in the politicoeconomic make-up of society. In building his argument, he is against "comfortable aestheticism," which he claims limits the question of intermediality to aesthetics or theoretical considerations alone. ${ }^{13}$ Using arguments from Rosalind Krauss and Dick Higgins, Schröter advances his case. On the one hand, Krauss argues that intermediality is a capitulation of art to the capitalist spectacle culture. ${ }^{\mathrm{I}}{ }^{\mathrm{O}} \mathrm{On}$ the other, Higgins considers intermediality as the "re-unification" of media, which began to be viewed as separate during the Renaissance period when "the division of society into different classes favoured the purification of media." Is Schröter argues that even

\footnotetext{
ı "Politics," Oxford English Dictionary, 2017, http://www.oed.com/viewdictionaryentry/Entry/237575 (accessed 22 July 20I7).

II Ibid.

I2 Ibid.

I3 Schröter, 20Io, p. Io8.

${ }^{14}$ Ibid., p. II3.

is Ibid., p. II4.
} 
though the two viewpoints have different premises, intermediality is interpreted in both as "the symptom of a capitulation of aesthetic strategies to the mise-en-scène strategies of the capitalist spectacle." ${ }^{16}$

Schröter suggests three dimensions to the study of the "politics of intermediality." 17 The first type emphasizes the historicity of this concept. This would involve the historical reconstruction of theoretical approaches to intermediality to analyze and sketch out their political implications in the context of their specific historical backgrounds. The second type of study emphasizes a social angle to the question of intermediality. It would analyze how different social groups, classes, strata, or institutions, even when located in the same culture, practically operate with intermedial processes in different ways. The third type has an intercultural focus: it compares how different cultures understand the differences between media and their interaction in a given historical phase.

In some ways, the present article integrates aspects of all three dimensions outlined by Schröter. It gives a historical overview of some of the theoretical approaches to intermediality in African theatre theory while acknowledging the divergence of the various African theatre contexts and how their (historical, political, and cultural) differences influence their conceptualization of media interrelations. An example of this is its understanding of the different attitudes towards intermediality in Anglophone and Francophone Africa, but also within the Anglophone African theatre. It also attempts to account for the differences between how African and Western theatre scholarly cultures understand intermediality in the same historical phase. Ultimately, my main argument is that to discuss the politics of intermediality in African theatre contexts is to explore the assumptions underlying the activities, theory, and attitudes towards intermediality in specific African theatre contexts. This article, therefore, sustains an awareness that writing and theorizing about intermediality unfolds in a specific social and historical context, that intermediality is "closely intertwined with particular social and institutional practices. ${ }^{\text {I }}$

\footnotetext{
${ }^{16}$ Ibid., p. II3.

${ }^{17} \mathrm{Ibid}$., p. I2O-I2I.

${ }^{18}$ Müller, 20IO, p. 17.
} 


\section{INTERMEDIALITY}

The term "intermediality" has a long history of usage in a wide array of disciplines, such as literature, visual arts, and media studies. In theatre studies, intermediality draws from media, performance, and perception theories. ${ }^{19}$ According to Irina Rajewsky, ${ }^{20}$ intermediality in the broadest sense means: relations between media, media interactions, and interferences. In a narrower sense, these media relations, interactions, and interferences may be characterized in three categories: as transfers and transformations, references, and combinations and integrations. I ground my conceptualization of these subcategories in the schemas provided by Lars Elleström and Irina Rajewsky both of whom stress the need to consider these subcategories as distinctions that are primarily intended to facilitate thinking about and analyzing media. ${ }^{21}$

For Rajewsky, ${ }^{22}$ media transpositions or transformations imply the way in which a media product comes into being, with the transformation of another media product. Similarly, Elleström argues that this subcategory emphasizes an understanding of media that includes a temporal gap among media products, media types, and media traits - "either an actual gap in terms of different times of genesis or a gap in the sense that the perceiver construes the import of a medium on the basis of previously known media." ${ }_{23}$ An example of media transformation is when a novel becomes a source medium for a newly made film.

${ }^{19}$ Freda Chapple and Chiel Kattenbelt, "Key Issues in Intermediality in Theatre and Performance," in Freda Chapple and Chiel Kattenbelt (eds.), Intermediality in Theatre and Performance, Amsterdam, Rodopi, 2006, p. I2; Kati Röttger, "The Mystery of the InBetween: A Methodological Approach to 'Intermedial Performance Analysis', Livre sur le théâtre et l'intermédialité en français, Montreal, 2013. This is an unpublished article that can be found here: http://www.uva.nl/binaries/content/documents/personalpages/r/o/k.e.rottger/nl/tabbladvier/tabblad-vier/cpitem\%5B2\%5D/asset?1360854346985

${ }^{20}$ Irina O. Rajewsky, "Border Talks: The Problematic Status of Media Borders in the Current Debate about Intermediality," in Lars Elleström (ed.), Media Borders, Multimodality and Intermediality, Basingstoke, UK, Palgrave Macmillan, 20IO, p. $5 \mathrm{I}$.

${ }^{21}$ See Lars Elleström, Media Transformation: The Transfer of Media Characteristics among Media, Basingstoke, UK, Palgrave Macmillan, 20I4, p. 3; Rajewsky, 20Io, p. 54; and Irina Rajewsky, "Intermediality, Intertextuality, and Remediation: A Literary Perspective on Intermediality," Intermediality: History and Theory of the Arts, Literature and Technologies, no. 6, "remédier/remediation," 2005, p. 54-55,

${ }^{22}$ Rajewsky, 20I0, p. 5 I.

${ }^{23}$ Elleström, 20I4, p. 3. 
According to Rajewsky, ${ }^{24}$ the intermedial quality in media references has to do with the way in which the media product "uses its own media-specific means, either to refer to a specific, individual work produced in another medium, or to refer to a specific medial subsystem or to another medium qua system.” 25 Intermedial references often involve the evocation or imitation of (techniques/conventions/practices) of one medium by or within another. For example, the evocation of certain filmic techniques such as montage editing and zoom shots in a theatrical performance is an intermedial reference. I should note that while Rajewsky considers intermedial references as a subcategory of intermediality, Elleström ${ }^{26}$ believes that Rajewsky's two categories, medial transposition and intermedial references, should be understood within the frames of media transformation.

Lars Elleström argues that understanding media in terms of combination and integration of fundamental media traits implies an understanding of media as coexisting media products, media types, and media traits. ${ }^{27}$ In media combination, the very process of combining at least two conventionally distinct media or medial forms of articulation determines the intermedial quality. As Rajewsky writes: "These two media or medial forms of articulation are each present in their own materiality and contribute to the constitution and signification of the entire product in their own specific way." ${ }^{28}$ An example of media combination is when a theatrical performance combines and integrates basic media such as auditory text, still image, and body performance, but also other qualified media such as puppetry or animation film.

In reference to theatre in particular, Elleström argues that theatre is by definition a phenomenon of media combination. ${ }^{29}$ This is because theatre normally combines and integrates, to varying degrees, basic media ${ }^{30}$ such as auditory text, still

\footnotetext{
24 Rajewsky, 2005, p. 53-54.

25 Ibid., p. 53.

${ }^{26}$ Elleström, 20I4, p. 9.

${ }_{27}$ Ibid., p. 3.

${ }^{28}$ Rajewsky, 2005, p. 52.

29 Elleström, "The Modalities of Media: A Model for Understanding Intermedial Relations," in Elleström (ed.), 2010, p. 28.

$3^{30}$ Elleström regards basic and qualified media as abstract categories that help us understand how media types are formed by very different sorts of qualities. Elleström uses the term "basic media” for those media that are mainly identified by their modal appearances. In contrast,
} 
image, and body performance, but also qualified media such as film. Theatre is understood and defined as a qualified ${ }^{31}$ medium partly based on the aesthetic aspects of these combinations and integrations of basic media and qualified media: "Theatre may thus be said to be a qualified medium that is very much multimodal and also, in a way, very much intermedial since it combines and integrates a range of both basic and qualified media." ${ }^{32}$ Nevertheless, Elleström also argues that all media products can be investigated from both a synchronic perspective in terms of combination and integration and a diachronic perspective in terms of transfer and transformation. ${ }^{33}$

It should be noted that the present article also regards theatre and all other arts as media. In taking this stance, the article is influenced by a shift in recent art and media theoretical discourses whereby there is a recognition that the arts and media should not be studied in their own historical developments and with their own rules and specifications, but rather in the broader context of their differences and corelations. ${ }^{34}$ This shift is summarized by Peter Boenisch:

We have to accept that there simply has never been a separate history of theatre and media in the first place. Theatre itself is a media technology that utilizes, at its very heart, other media to transmit and store, while it highlights, at the same time, the process of processing information. ${ }^{35}$

The shift in recent art and media theoretical discourses is a response to approaches that emphasize medial specificity and essentialism, which pits various arts and other media against each other, as if "they all presided over their own distinctly defined aesthetic realms." ${ }^{36}$ In this latter approach, theatre, "if it is regarded as media at all, is

"technical media" are the tangible devices needed to materialize instances of media types. Ibid., p. I2.

${ }^{31}$ According to Elleström, "[q]ualified media are aspects of a medium characterized by historical, cultural, social, aesthetic, and communicative facets." Ibid., p. 5 .

${ }^{2}$ Ibid., p. 29.

33 Elleström, 20I4, p. 4.

${ }^{34}$ Chiel Kattenbelt, "Intermediality: A Redefinition of Media and a Resensibilization of Perception,” paper presented at the Intermediality: Performance and Pedagogy Conference, Sheffield University, Sheffield, UK, Is March 2007, p. I.

35 Peter Boenisch, "Aesthetic Art to Aisthetic Act. Theatre, Media, Intermedial Performance," in Chapple and Kattenbelt (eds.), 2006, p. II3.

${ }^{6}$ Ibid., p. I03. 
seen as an ancient one that has had its day while media experiences of film, television and the computer are regarded as inauthentic and vicarious." ${ }^{37}$

A common misconception leads scholars to define intermediality as a new phenomenon. ${ }^{8}$ This perspective disregards the fact that the concept of intermediality is involved in the historical unfolding of phenomena. Müller argues that intermediality should be regarded as a search term because the concept is bound up in an ongoing process of development. ${ }^{39} \mathrm{I}$ find value in this approach because it takes into account the progressive unfolding of a historiography of intermedia processes in specific social and historical contexts. In Müller's schema, ${ }^{40}$ the artistic, material, and communication aspects (that can be termed intermedial) as well as their (historical) context of meaning-making are important considerations in designating something as intermedial. In other words, any theoretical undertaking towards a research axis of intermediality should be critical and must present its awareness in dealing with phenomena strongly subject to transformation. Writing about intermediality in African theatre contexts therefore should take into account their "particular artistic, material, media-related and communicative forms of action," but also the "context of production of meanings that grow from these actions for a particular historical audience or historical users." ${ }^{\mathrm{I}}$ The next section traces theatrical intermediality before discussing intermediality in African theatre contexts.

TRACING THEATRICAL INTERMEDIALITY

The publication of Intermediality in Theatre and Performance,,$^{42}$ edited by Freda Chapple and Chiel Kattenbelt, marked a critical step in delineating the field of theatrical intermediality. Even though theatre scholars have been debating the interrelations between theatre and other arts and media for centuries, the use of the term "intermediality" to characterize these relations has become popularized since this publication. Consisting of essays that discuss intermedial relations created when theatre and the performing arts intersect with cinema, puppetry, television, and

37 Christopher Balme, "Audio Theatre: The Mediatization of Theatrical Space," in Chapple and Kattenbelt (eds.), 2006, p. II7.

${ }^{38}$ Scholars who confine their understanding of intermediality to the advent of digital media are often guilty of this. See Rajewsky, 2005, p. 44.

39 Müller, 20Io, p. I6.

40 Ibid., p. 17.

${ }^{41}$ Ibid.

${ }^{42}$ Chapple and Kattenbelt (eds.), 2006. 
digital technology, the publication presents a strong argument for reconstituting theatre as an intermedial phenomenon. This collection of essays was the first official publication to result from the Intermediality in Theatre and Performance Working Group of the International Federation for Theatre Research, which was founded in 1998. The book is known to have explored the centrality of the concept of the "inbetween" in its conceptualization of intermediality.

The second publication from the members of the working group, Mapping Intermediality in Performance, ${ }^{43}$ edited by Sarah Bay-Cheng, Chiel Kattenbelt, Andy Lavender, and Robin Nelson, exemplifies a shift towards a particularly vested interest in digital culture in theatrical intermediality. The editors of the book underscored this shift in their introduction:

Building then upon the earlier volume and subsequent publications by IFTR [International Federation for Theatre Research] group members, this book affords a tighter focus than the last publication on digital culture and the implications for theatre of what has been called the "intermedial turn." ${ }^{4}$

In another departure from its predecessor, Mapping Intermediality in Performance also presents a response to and an adaptation of Elleström's Media Borders, Multimodality and Intermediality. It adopts Elleström's "both-and" approach towards intermediality, in place of the "in-between" focus of the first publication, using the new approach to reposition claims for the distinctiveness of intermediality in digital culture. ${ }^{45}$ These publications and many others ${ }^{46}$ on the same topic

\footnotetext{
${ }^{43}$ Sarah Bay-Cheng, Chiel Kattenbelt, and Andy Lavender (eds.), Mapping Intermediality in Performance, Amsterdam, Amsterdam University Press, 2010.

44 Robin Nelson, "Introduction: Prospective Mapping and Network of Terms," in BayCheng, Kattenbelt, and Lavender (eds.), 20Io, p. I5.

45 Bay-Cheng, Kattenbelt, Lavender (eds.), 2010, p. I5.

46 There are many publications outside the IFTR framework on the subject of intermediality in theatre. The list below presents some of them: Greg Giesekam, Staging the Screen: the Use of Film and Video in Theatre, Hampshire, Palgrave Macmillan, 2007; Claudia Georgi, Liveness on Stage: Intermedial Challenges in Contemporary British Theatre and Performance, Berlin, Walter de Gruyter, 20I4; Aneta Mancewicz, Intermedial Shakespeares on European stages, Basingstoke, UK, Palgrave Macmillan, 2014.

Huallid Amīn and George F. Roberson, Intermediality, Performance and the Public Sphere: Selected Papers from Recent Meetings of the Tangier International Conferences, Amherst, Collaborative Media International, 20I4; Mary Simonson, Body Knowledge: Performance,
} 
demonstrate how vast the field of intermediality is in the theatre context. Following recent trends in intermedial theatre practices, theatre studies as a discipline is continuously redefining theatre as a qualified medium predisposed to intermediality.

\section{INTERMEDIALITY IN AFRICAN THEATRE?}

Scholars 47 writing about African theatre from various disciplines have been discussing media interrelations through the use of related concepts such as interartiality, hybridity, and syncretism. These concepts are not synonymous with intermediality but they share some aspects with it.

The notion of interartiality can be seen as a relative of intermediality. Scholars such as Müller have also discussed this link. $4^{8}$ Conversations about the interrelations among the arts are not a new phenomenon in African theatre discourse. There is a long history of scholars who have conceptualized these interrelations. For instance, Ngũgĩ wa Thiong' ${ }^{49}$ posits that there is an interconnectedness of art forms in the African context and a fluidity among drama, story, song, discourse, and performance, whereby the wholeness of all is bigger than the individual parts that contribute to it. Of note is Ngugi's willingness to add digital forms such as cyber-orature to his schema. Similarly, Steve Chimombo advances a comparable framework in his conceptualization of Malawian arts and aesthetics. ${ }^{50}$ Chimombo argues that there is no linguistic discrimination among the arts in Malawian cultures, since all the arts are

Intermediality, and American Entertainment at the Turn of the Twentieth Century, Oxford, Oxford University Press, 2013.

47 See examples from Du Preez, wa Thiong'o and Lavender.

${ }^{48}$ Müller, 20Iо, p. I9.

49 See Ngũgĩ wa Thiong'o, "Notes towards a Performance Theory of Orature," Performance Research, vol. I2, no. 3, 2007, p. 5. In the article, wa Thiong'o introduces the term "orature" as used by the Ugandan linguist Pio Zirimu and the South African artist Pitika Ntuli. Even though the article could be said to propose a theory of orature in general, without referring to any particular context, the examples that wa Thiong'o gives are from several African contexts such as Kenya (from his own mother tongue Gikuyu), Nigeria (in reference to the work of J. P. Clarke and Chinua Achebe), and Uganda and South Africa (with examples from Zirimu and Ntuli). Also note that Ntuli, on whose theory wa Thiong'o bases his article, discusses the nature of African orature in general and in comparison with the West.

so Steve Bernard Miles Chimombo, Malawian Oral Literature: The Aesthetics of Indigenous Arts, Zomba, Centre for Social Research, 1988. Chimombo proposes a theory of Malawian aesthetics and orature. Even though his analysis is specific to the Chichewa language and Chewa aesthetics, it could be comparable to any other language of the Bantu language cluster from Central, East, and Southern Africa. 
united under the $-\mathrm{mb}$ - linguistic principle ${ }^{\mathrm{SI}}$ in the Chichewa-speaking group. In this argument, Chimombo implies that the art forms in this particular context are linguistically, and therefore conceptually, interconnected. Conversations such as these should be regarded as precursors to the intermediality debate. When considered in this way, the current focus on the interrelations between theatre and electronic or digital media are merely newer discussion points in the same conversation on the interrelations among media. The study of intermediality in these African theatre contexts, therefore, departs from these conversations.

The notion of hybridity can also be looked at in relation to intermediality. There are several parallels and overlaps between the two concepts. Some scholars use the terms in a similar way, considering one of them as a subcategory of the other, specifically to denote plural-medial or media combination forms. For example, in Trends in Twenty-first Century African Theatre and Performance, Petrus Du Preez argues:

[...] the nature of African theatre performance (and the various art forms) in the $2 \mathrm{I}^{\mathrm{st}}$ century is fundamentally rooted in the concept of hybridity. Contact with and influences of mass media forms such as television, films, radio and the Internet underline $[\mathrm{s}]$ this view. ${ }^{52}$

In this quote, Du Preez's conceptualization of hybridity includes aspects of media interrelations. However, the current usage of the terms "hybrid" and "hybridization" in cultural studies depicts a rather heterogeneous use of the concept.

The concept of hybridity is of great significance to postcolonial studies. According to Andy Lavender, the question of boundaries has consistently

${ }^{\mathrm{I}} \mathrm{-mb}-$ is a common nasal consonant cluster in a lot of words that denote various forms of creativity in Chichewa. These include the words that denote singing, kuyi(mb)a and ceramics, kuwu $(m b) a$.

52 Petrus Du Preez, "The Tall Tale of Tall Horse: The Illusion (or Manifestation) of African Cultural and Traditional Aesthetics in Hybrid Performances," in Kenechukwu Igweonu(ed.), Trends in Twenty-first Century African Theatre and Performance, Amsterdam, Rodopi, 20II, p. 139. In this book chapter, Du Preez provides a reading of Tall Horse, a collaborative and hybrid work produced by the South African Handspring Puppet Company and the Sogolon Theatre of Mali. The chapter generalizes "African theatre" even though it also problematizes the concept of "African identity" in the theoretical approaches to theatre and performance studies in Africa. 
preoccupied theorists of hybridity. ${ }^{53}$ This question would later preoccupy theorists of intermediality. Homi Bhabha problematizes the cultural and political value of hybridity. In his analysis, hybridity may be imposed by colonialism, or appear in colonialist discourse as the emergence of a disavowed Other. ${ }^{4}$ Hybridity has therefore been theorized as a product of the complex cultural interactions that took place in the post-colony, from the colonial period to the present, and the resultant uncertain crossings and invasions, some of which are medial in nature.

Similarly, there are parallels between intermediality and syncretism. Syncretism implies the mixing of and the bringing together of a diverse set of forms, practices, and traditions (some of which are medial in nature) to create a new form or a particular work of art. Christopher Balme defines theatrical syncretism as "the process whereby heterogeneous signs and codes are merged together." 55 He further describes it as "a conscious programmatic strategy to fashion a new form of theatre in the light of colonial and postcolonial experience." 56 In African theatre, syncretism is about the fusion of performance idioms from indigenous traditions with the Western dramatic form. Balme presents syncretic theatre as one of the most effective means of "decolonizing the stage," since it utilizes the performance forms of both European and indigenous cultures in a creative recombination of their respective elements. 57

\section{TOWARDS AN UNDERSTANDING OF INTERMEDIALITY IN AFRICAN THEATRE CONTEXTS}

Regarding the incorporation of electronic or digital media in African theatre contexts, a review of recent literature on contemporary African theatre practices reveals that scholars are starting to discuss the incorporation of media technologies under the topics "mixed media techniques" and "multimedia performance." 58

${ }^{3}$ Andy Lavender, Performance in the Twenty-First Century: Theatres of Engagement, London, Routledge, 2016, p. 59.

54 Ibid., p. 76.

ss Christopher Balme, Decolonizing the Stage: Theatrical Syncretism and Postcolonial Drama, Oxford, Clarendon Press, I999, p. I.

${ }_{56}^{6}$ Ibid.

57 Ibid., p. 2.

${ }^{8}$ The works cited below are postgraduate dissertations from South African institutions of higher learning: Gaerin Hauptfleisch, Media and the Theatre: A Practical Study on the Uses of Film, Television and Video in Two South African Productions, master's dissertation, Stellenbosch, Stellenbosch University, 1999; Moratiwa Molema, Layering Time: The Representation of Tradition in Contemporary Multimedia Performance, master's dissertation, 
However, most discussions on theatre and media technologies still tend to focus on an antagonistic relationship between them, often with one (media technologies) threatening to or intending to take no account of the other (theatre). 59 Their viewpoint is largely based on the fact that mass media forms are currently dominant at the cultural economy level, at the expense of theatre. This thinking can be critiqued for ignoring media interrelations as an outcome resulting from the intersections of or coexistence between old and new media forms.

Key scholarly texts on theatre or media in Africa have also overlooked the multifaceted dimensions of the interrelations among media. Ironically, the inclusion of other artistic media forms in key theatre texts is a trend in African theatre scholarship. ${ }^{60}$ This inclusion is an indication that scholars in African theatre recognize that theatre and other media belong to the same conceptual realm. However, grounded in a context of restrictive disciplines, these key texts have maintained an emphasis on borders between genres, disciplines, and categories, and have since perpetuated the tendency to view African theatre as monolithic. For example, Susan Arndt, Eckhard Breitinger, and Marek Spitczok von Brisinksi's Theatre, Performance and New Media in Africa discuss theatre, music, video, film, and popular print media as separate and distinct genres. Similarly, David Kerr's edited volume African Theatre Io: Media ES Performance discusses more examples of media-specific genres than those that interrelate. Another key text, Kenechukwu Igweonu's Trends in Twenty-first Century African Theatre and Performance, ${ }^{61}$ does

Cape Town, University of Cape Town, 2008; Dominik Lukasz Pater, Biography and the Digital Double: The Projected Image as Signifier in the mise-en-scene of Live Performance, master's dissertation, Johannesburg, University of the Witwatersrand, 2orr. See also Kerr (ed.), 2OII.

59 See Udengwu, 20II, p. 342; Inyang, 2008, p. 2; Nwanko, 20I0, p. 34; Rantimi, 20Io, p. 229 .

6o This is reflected in the titles of the following books: Susan Arndt, Eckhard Breitinger, and Marek Spitczok von Brisinski (ed.), Theatre, Performance and New Media in Africa, Eckersdorf, Germany, Thielmann \& Breitinger, 2007; and Kerr, 20II. These books are characterized by a more inclusive understanding of what the fields of theatre and performance entail.

6r Kene Igweonu(ed.), Trends in Twenty-First Century African Theatre and Performance, Amsterdam and New York, Rodopi, 2oII. Igweonu's anthology includes articles from the South African, Tanzanian, Zimbabwean, and Nigerian theatre contexts. The anthology, for the large part, generally refers to "African theatre" even though it is explicit in its awareness that Africa is not one coherent and monolithic entity, "but a complex, 
not discuss media interrelations at all, even though it purports to provide an overview of trends in contemporary theatre practice.

However, contemporary practice in some African theatre contexts has been much more experimental in exploring media interrelations. Kerr, for example, reports that, because of its well-equipped theatres, South Africa has taken the lead in mixed media stage techniques. ${ }^{62}$ Perhaps this explains why there have been a number of drama theses from South African universities that have investigated the incorporation of media technologies in South African theatre in the last two decades. Examples of these are Gaerin Hauptfleisch, Moratiwa Molema, and Dominik Lukasz Pater. ${ }^{63}$ Kerr also notes that the practice of mixing live and electronic performance is beginning to take root outside the South African theatre context. ${ }^{64}$ In his edited volume mentioned above he introduces two examples of such contemporary practices by artists from Botswana and Kenya.

African Theatre Io: Media ES Performance is the most recent publication that investigates the interrelations between African theatre, performance, and various forms of media. Even though intermediality is not the focal point of this publication, the juxtaposition of theatre, performance, and other media, explicit in the title of the volume and the discussion of mixed media stage techniques, indicates a shifting approach towards understanding medial interrelations in African theatre contexts.

The incorporation of electronic media into theatrical performances, discussed in Kerr's edited volume, is an example of the nature of interrelations (between theatre and other media) that are investigated through the concept of intermedialityinterrelations that blur the boundaries between media (and subsequently between genres, disciplines, and categories) in theatre performance. Kerr's approach towards "mixed media stage techniques," while a useful point of departure, could be critiqued for assuming that media interrelations always involve digital or electronic technology. In contrast, other literature discusses examples of interaction between theatre and other media that are not induced by digital or electronic media technology. ${ }^{65}$ These examples, together with experiments with electronic and digital media, are both crucial to the understanding of intermediality in African theatre contexts.

polysystemic amalgam of many political, linguistic, social, cultural and economic sub-systems.” Ibid., p.Io.

${ }^{62}$ Kerr, 20II, p. xvii.

${ }_{63}$ Hauptfleisch, 1999; Molema, 2008; and Lukasz Pater, 201 .

${ }^{6} \mathrm{Kerr}, 2 \mathrm{oII}, \mathrm{p}$. xviii.

6s Chapple and Kattenbelt (eds.), 2006, p. II-I2. 
$I_{29}$ Inspired by the groundwork set in African Theatre Io: Media E Performance, my own $\mathrm{PhD}$ study ${ }^{66}$ investigated media interrelations through an analysis of four theatrical performances from festivals in Malawi and South Africa in 20I4, in order to unearth how intermediality manifests in these contexts.

For my first case, I analyzed media combination and integration in William Kentridge, Jane Taylor, and Handspring Puppet Company's Ubu and the Truth Commission (2014) (see Fig. I). ${ }^{67}$ The performance combined and integrated media such as actors' bodies on stage, puppetry, shadow theatre, and projection (of an animated film and a multimedia documentary film) in order to present several intertwined story-worlds, drawing out themes relevant to the creative team and to the nation at large in the immediate post-apartheid era. The re-staging of Ubu in 2014 at the National Arts Festival in Grahamstown-17 years after its original premiere there- - using the same media technologies it had used before, demonstrated that the incorporation of other media in the theatrical performance was less about the experimentation with new technologies and more about the use of suitable modes of representation for the depiction of traumatic experiences. My central argument in this case was that the creative team employed intermedial strategies in order to enable the exploration of complex post-apartheid themes such as private and public trauma, memory/self-anamnesis, arbitrary power, and madness and truth.

I established how the employment of animation, documentary film, and puppetry, which enabled the representation of alternative worlds, but still interrelated with the story-world presented by the actors on stage, was an important intermedial strategy in itself. On the one hand, the representation of the historically factual witness accounts from the Truth and Reconciliation Commission hearings was enabled through the use of witness puppets, invoking a (fragmented) multiangular relationship between the puppet, the puppeteer, and the translator in the construction of meaning from the spectator's perspective. Rather than re-performing the testimonies through the use of actors on stage, the performance displaced their re-telling through the use of puppetry.

\footnotetext{
${ }^{66}$ Makhumula, 2017. Even though this work is explicit in its focus on four examples from two specific contexts, it does make some generalized inferences about African theatre in some instances.

67 For more on the production, visit its webpage at: http://www.handspringpuppet.co.za/our-work/handspring-productions/ubu-and-thetruthcommission/ (accessed 25 March 2018).
} 
On the other hand, the representation of apartheid horrors is enabled through the use of the animation and documentary film on the screen, invoking figurative and representative modes. The images of hanging, detention, parcel bombs, torture depicted in the animation, for example, are the audience's only window into the clandestine nocturnal activities of Ubu and his henchmen (represented both on stage and on screen by a three-headed dog).

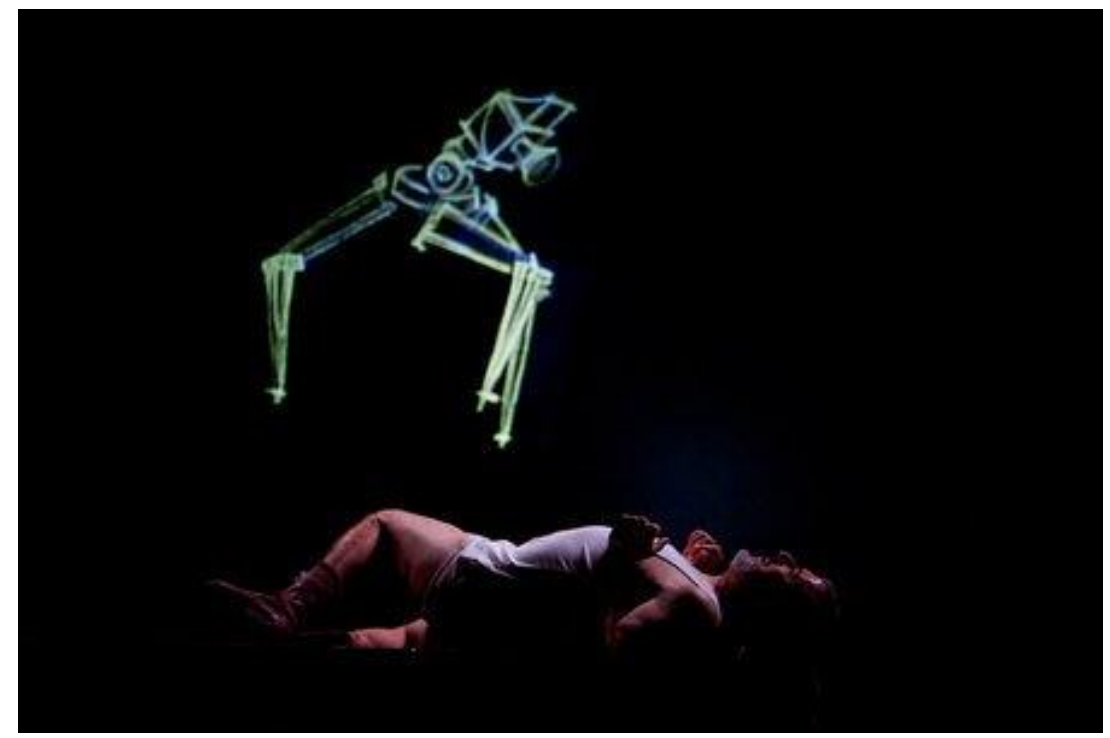

Fig. I. Photography of the play Ubu And The Truth Commission, the handspring Puppet company, William Kentridge and Jane Taylor, 20I4 @ Canadian Stage.

For my second case, I analyzed the transmediation of the Bluebeard fairy-tale in Gopala Davies' Barbe bleue: A Story of Madness (2014) (see Fig. 2). The study found that the performance experimented with multiple narration strategies in its treatment of an old fairy-tale. I argued that the director of the performance thematized the transmediality of the tale: its capacity to be retold across a variety of media. The resulting performance evoked complex visual and auditory storytelling experiences within the theatrical time and space. This was achieved through the interplay of complex layers of visuality and aurality consisting of corporeal bodies, auditory voices, images, film, and various projection techniques.

In my analysis, I categorized Barbe bleue into seven episodic scenes. Of these, the storytelling scene was the most complex. It consisted of a synchronized storytelling of the tale of Bluebeard that combined an auditory narrative, three visual 
narratives, and an embodied narrative. While most of these narratives would have sufficed on their own, the performance of Barbe bleue employed techniques that created a divergent range of visual and auditory experiences of the tale of Bluebeard in this scene. This experimentation was intended to critically engage the spectator with new, contemporary ways of looking and hearing, thereby exploring new ways of how the audience experiences theatre and theatrical presence.

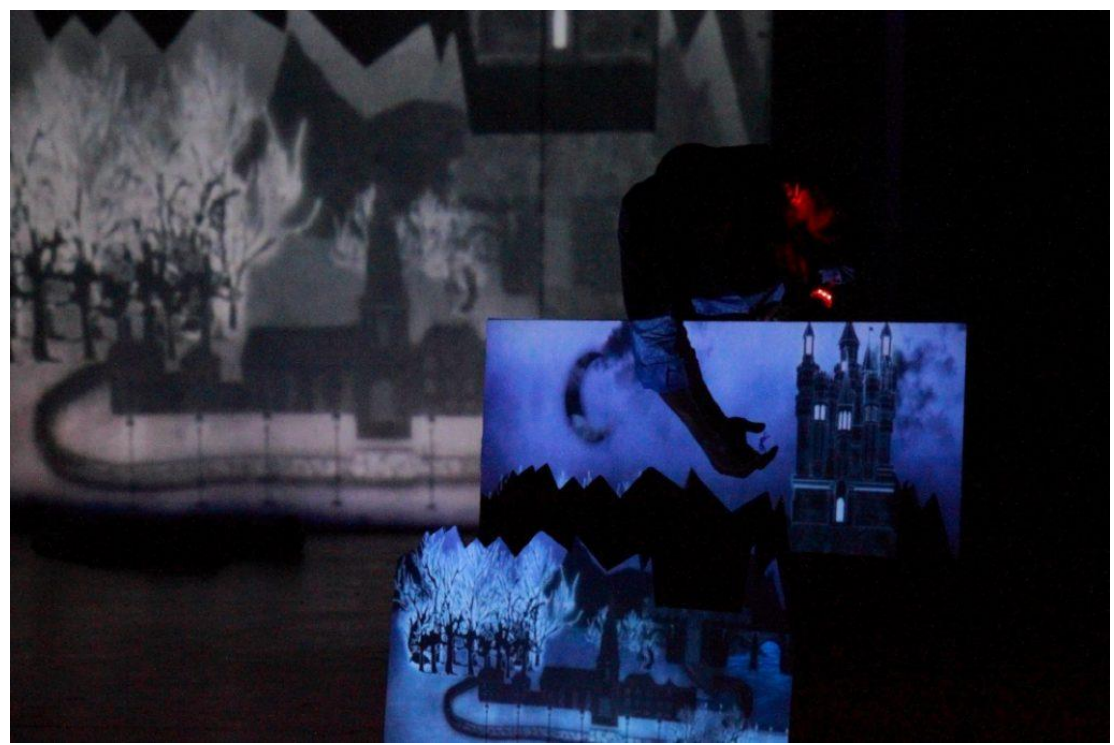

Fig. 2. Photography of the play Barbe Bleue: a Story of Madness, Gopala Davis, 2014. (C) Spiro Schoeman.

In my third case, I discussed transfers and transformations from music to theatre in my own work, Mwana wanga (2014) (see Fig. 3). I considered a recorded song as the source medium for a theatrical performance, and I discussed the ways in which Mwana wanga came into being from Dearest Child, a song by Kimba Mutanda. Through an analysis of the performance, I located the creative process of the theatre project as a critical site for media transposition. My main argument was that there is a complex process of transfer and transformation of media characteristics and traits in the interrelations between Dearest Child and Mwana wanga: that the inspiration from Dearest Child in Mwana wanga goes beyond the appropriation of themes and motifs, but also includes the transfer and transformation of aesthetic conventions, principles of structure, and stylistic procedures.

The study, therefore, discussed how the creative process of Mwana wanga transformed an existing relationship between the listener and a recorded song into 
one between a performer on stage and an audience. Specifically, I discussed how the body in performance translates the themes and motifs that were communicated through the medium of music. I highlighted the transfer of "text" and the verbal and instrumental melody of the song as examples of the straightforward transfers from song to performance. I also discussed how the letter-writing motif and the theme of post-independence disillusionment were re-signified during the transformation from music to theatrical performance.

For the fourth and final case, I analyzed intermedial references in Msonkhano.de/Begegnungen.mw (Encounters) (Macarthur Matukuta, 20I4) (see Fig. 4), an intercultural theatrical performance by Solomonic Peacocks Theatre (from Blantyre, Malawi) and Fräulein Wunder AG (from Hannover, Germany). This performance consisted of intermedial references to documentary film and photography through the use of theatrical means. I argued that the employment of "referred media" in the performance enabled the creative team to achieve a complex and continuous shifting of frames between the factual and fictional realms within the theatre setup in order to explore a contentious topic. The employment of "referred media" in the performance enables the creative team to "invent" a factual frame of representation using the techniques and sensory and spatiotemporal qualities of the referred medium. The creative team therefore attempted to present the (referred) documents as "objective conduit to reality," while the performance was deeply rooted in "the subjectivity at the heart of production and reception." 68 This constant shifting of frames was an essential tool for blurring the two realms of reality in the exploration of the theme of cultural exchange, which could be considered ordinary, but also controversial at the same time.

In summary, all four cases in the study presented evidence that the theatre practice in these specific contexts is far more experimental in transcending the boundaries between theatre and other media, in contrast with the picture so far painted by scholarship. The study found that the cases reconfigured conventional conceptualizations of and expectations from theatre in their attempts to augment how the audiences experienced theatrical presence, time, and space.

${ }^{68}$ Janelle Reinelt, "The promise of documentary," in Alison Forsyth \& Chris Megson (eds.), Get Real: Documentary Theatre Past and Present, New York, Palgrave Macmillan, 2009, p. 13. 


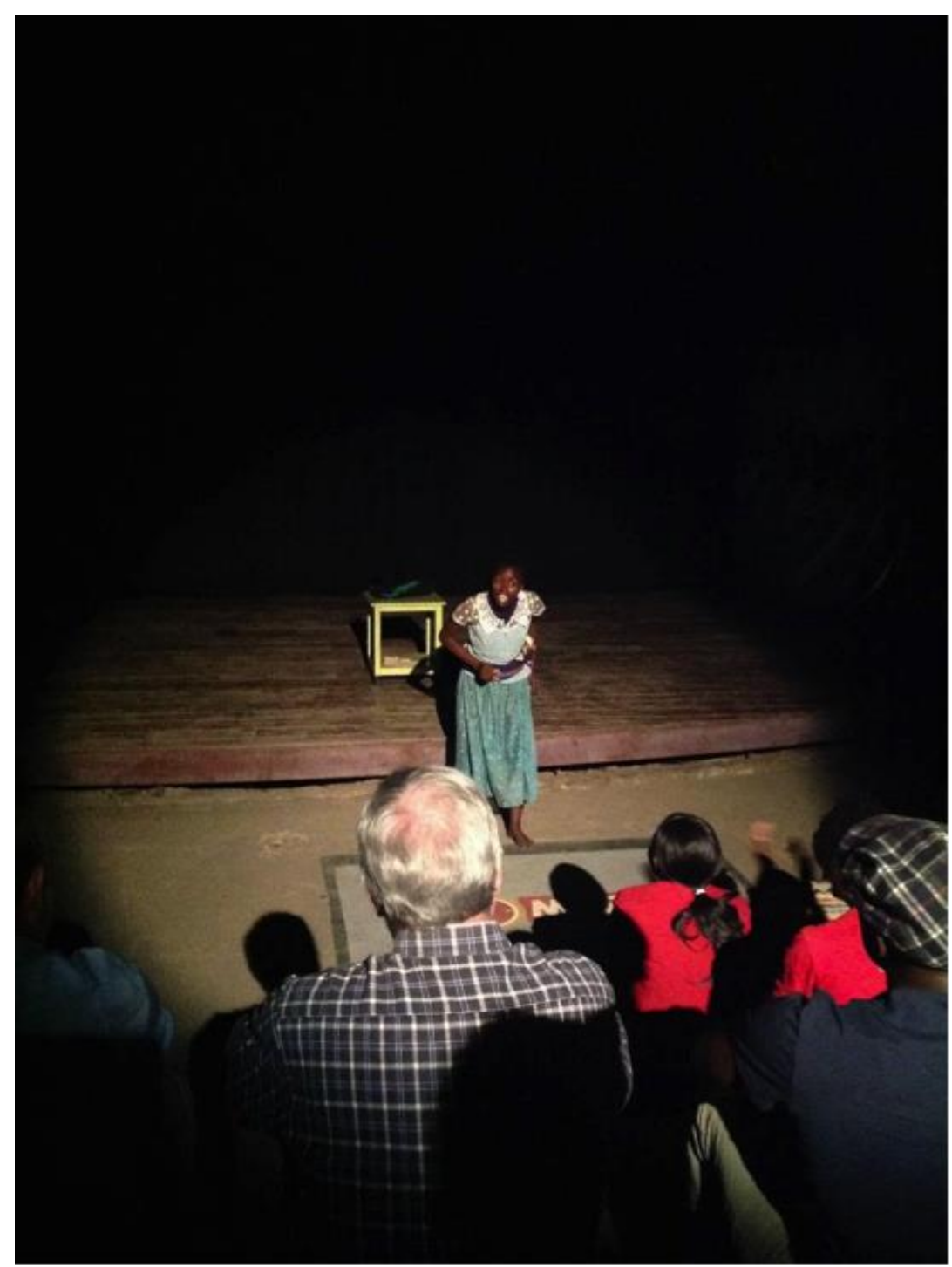

Fig. 3. Photography of the play $M W A N A W A N G A$, Catherine Makhumula, 2014. (c) Catherine Makhumula. 


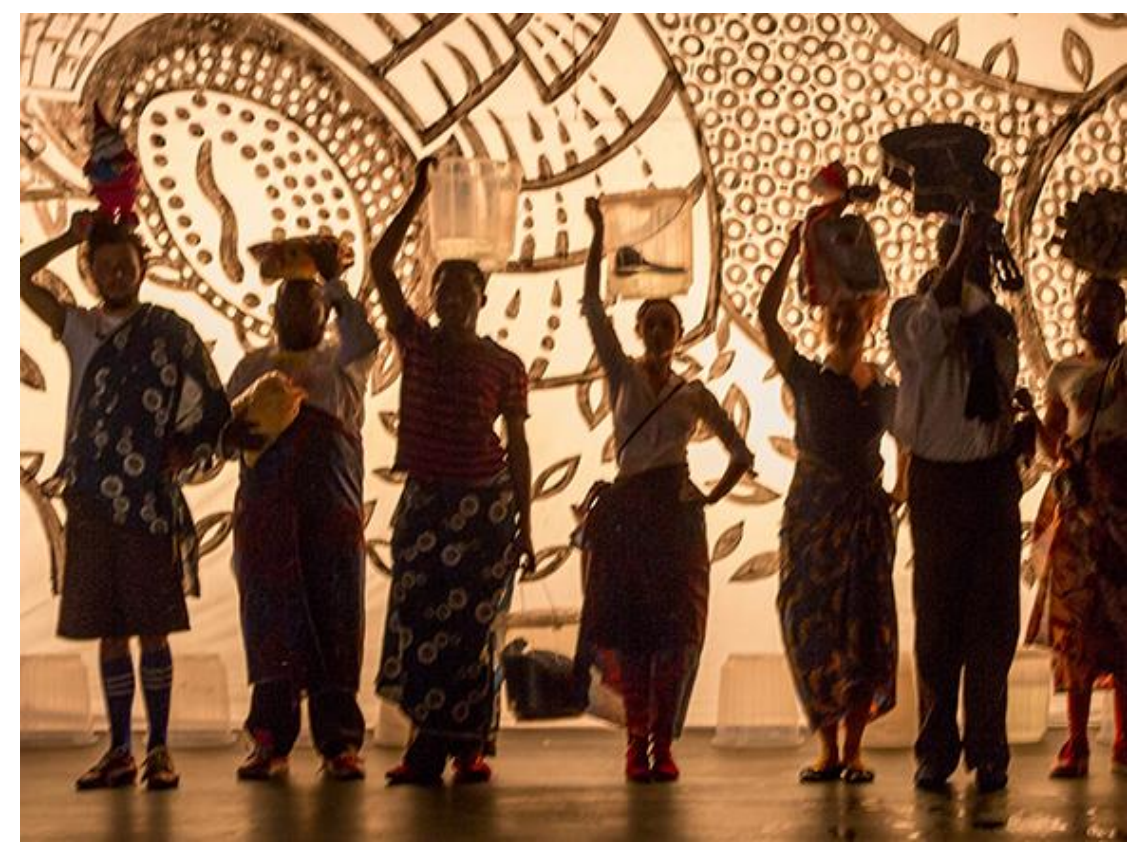

Fig. 4. Photography of the play Msonkhano.de/Begegnungen.mw, Fräulein Wunder AG, Hannover Germany and Solomonic Peacocks Theater company, 20I4. @ Moritz-Tittel.

\section{The Politics of Intermediality in African Theatre CONTEXTS}

As discussed in the introduction, the concept of intermediality is confronted with considerable scepticism and reserve by Anglophone scholars of African theatre. In contrast, contemporary theatre practice in some African contexts continually experiments with the transgression of media borders. This, therefore, indicates the politics of naming: how designating something as intermedial is not simply a theoretical or aesthetic issue but rather a political one.

In indicating the politics behind how African scholars discuss media, David $\operatorname{Kerr}^{69}$ observes that electronic media were introduced in Africa through colonial importation and therefore discussions on it are bound to carry aesthetic and ideological baggage. Kerr argues against a technocentric focus on media, which he claims tends to situate innovation within a paradigm dominated by technology,

${ }^{69}$ Kerr, 20II, p. xiv. 
ignoring the influence of African indigenous oral performative media: "[...] so that 'progressive' or 'avant garde' cultural innovations are projected as those associated with the latest media technologies." 70 This rationalization sheds light on the assumptions that underlie the attitudes of African theatre scholars, especially with regards to questions of media and power.

The attitudes of African theatre scholars towards the perceived narrow Western conceptualization of intermediality can also be exemplified by Christopher Odhiambo and Christopher Warnes' ${ }^{71}$ review of Robin Nelson's technocentric approach towards theatre in 2004. Commenting on Nelson's general approach to theatre, Odhiambo and Warnes consider the "intrusion" of technology as a "mediatising" agent for theatre to be a "worrying" phenomenon, because it negates the idea of theatre as the meeting of audiences and actors. ${ }^{72}$ Additionally, Odhiambo and Warnes argue that the influence of technology should not be such a grave matter, because "the theatrical events that still predominate in Africa, the Caribbean and most parts of the Indian subcontinent are in their 'pure' forms." 73

That Odhiambo and Warnes put "pure" in quotation marks expresses that they are aware that the claims of purity in African theatre are unfounded. Odhiambo and Warnes accurately note that the theatre in their context is not identical to the theatre described by Nelson. However, from their description of technology as "intruding" and "a worrisome phenomenon," Odhiambo and Warnes also demonstrate that not only they hold the view that technology has no place in African theatre, but that they also hold a prescribed and somewhat fixed view of what African theatre should or should not be. These sentiments are not compatible with the supposition that African theatre is not fixed.

In trying to account for the lack of enthusiasm about the concept of intermediality, I am inclined to speculate that the tendency to regard African theatre as dichotomous-composed of indigenous and Western aspects-leads to a narrow conceptualization of African theatre such as Odhiambo and Warnes' discussed above.

70 Ibid.

${ }^{71}$ Christopher Odhiambo and Christopher Warnes, "Extending the Possibilities of Theatre: Playing with Borders Dynamics Frames," South African Theatre Journal, vol. I8, no. I, 2004. This review generalizes African theatre without any specification of the theatre contexts they refer to. However, it is important to note that this review is from 2004, before many of the works on theatre and media in Africa cited in this article were written.

72 Ibid., p. 284.

73 Ibid. 
I am persuaded to think that such categorizations are limiting the analysis of contemporary African theatre. Departing from a similar premise, David Kerr ${ }^{74}$ observes a historical tendency to describe modern African theatre as dichotomous in most accounts of African theatre theory. He argues that discussions on African theatre theory tend to centre around the linked polarities of indigenous/popular performance on one side and imported/elitist theatre on the other. In this understanding, Western theatre is believed to classify specialized genres for spoken dialogue (drama), dance (ballet and mime), music (concert and opera), or fine art (painting and sculpture), while African performance is perceived to sustain a complex and tightly integrated synaesthesia. Kerr ${ }^{75}$ traces this tendency to H. E. Dhlomo who is considered the godfather of African theatre theory in his writings from the r93os. Dhlomo $^{76}$ suggested that a modern literary drama in Africa would need nourishment from both African and European sources. According to him, the notable features of the African root, which he described as "tribal drama," were its spontaneity and participatory qualities, its use of multimedia synaesthesia, and its ability to unite communities through a programme of social control.

In another attempt to account for the reserve and scepticism in the use of the concept of intermediality, I argue that the current tendency of Western scholars to emphasize the distinctiveness of intermediality in digital culture leads to the term's narrow conceptualization: in this view, intermediality seems to imply the interrelations between theatre and digital technologies. 77 This narrow conceptualization does not consider that the concept of intermediality is bound up in an ongoing process of development. Indeed, as I mentioned previously, scholars have noted a shift towards a vested interest in digital culture by Western theorists of

74 David Kerr, "African Theories of African Theatre," South African Theatre Journal, vol. IO, no. I, 1996. Kerr's article is an elaborate account of the various approaches, by both African and Western scholars, to African theory. It makes conclusions about African theatre after presenting and discussing the various theories of the origins of drama in specific national contexts such as Zimbabwe, Malawi, Zambia, South Africa, Nigeria, Ghana, Tanzania, Kenya, and Cameroon.

75 Ibid.

${ }^{76}$ H. I. E. Dhlomo, "Drama and the African," English in Africa, vol. 4, no. 2, 1977. In contrast with Kerr's article cited above, Dhlomo, in this article, generalizes Africa and African theatre without reference to their particular historical, political, cultural, and artistic context.

77 I discuss the shift towards a particularly vested interest in digital culture in theatrical intermediality in the section titled "Tracing theatrical intermediality.", Makhumula, 2017. 
theatrical intermediality $7^{8}$ exemplified by a large collection of recent literature such as Steve Dixon's Digital Performance: A History of New Media in Theater, Dance, Performance Art, and Installation, 79 Greg Giesekam's Staging the Screen: The Use of Film and Video in Theatre, ${ }^{80}$ Nick Kaye's Multi-Media: Video-InstallationPerformance, ${ }^{8 \mathrm{I}}$ Jennifer Parker-Starbuck's Cyborg Theatre: Corporeal/Technological Intersections in Multimedia Performance, ${ }^{82}$ and Rosemary Klich and Edward Scheer's Multimedia Performance. ${ }^{83}$ When the conceptualization of intermediality is limited to advancements and experimentation with digital media, it is easy to see how African theatre and performance scholars such as Kerr and Odhiambo and Warnes are cautious about a technocentric approach towards media interrelations.

Also against this approach to intermediality, Müller argues that research in the intermedial field should not rest contented with the (rather too simple) answer that the digital will lead to new overlaps and multimodal combinations of media each of which formerly existed on its own. ${ }^{84}$ Müller argues that "we should rather ask to what extent and how traditional audio-visual media and/or analogic sounds and images have left their traces in these digital worlds, what modalities could be reconstructed, and what social functions result from these processes for the users of so-called new media." " s Considered this way, the digital age would not prompt the end of intermediality research. It would only form a new challenge regarding the reconstruction of an interconnected history of digital media. ${ }^{86}$

The shift towards digital culture in the recent accounts of theatrical intermediality is also in contradiction with the assertion by other scholars of theatrical intermediality that the concept of intermediality goes beyond the technological aspects of media. This is because approaches that emphasize the technological aspects

${ }^{78}$ See Mancewicz, 20I4, p. 8.

79 Steve Dixon, Digital Performance: History of New Media in Theater, Dance, Performance Art, and Installation, Cambridge, MA, The MIT Press, 2007.

8o Giesekam, 2007.

8I Nick Kaye, Multi-Media: Video-installation-performance, New York, Routledge, 2007.

82 Jennifer Parker-Starbuck, Cyborg Theatre: Corporeal/Technological Intersections in Multimedia Performance, New York, Palgrave Macmillan, $201 \mathrm{.}$.

${ }_{3}$ Rosemary Klich and Edward Scheer, Multimedia Performance, New York, Palgrave Macmillan, 20II.

84 Müller, 2oIo, p. 33.

85 Ibid.

86 Ibid. 
of intermediality tend to assume that intermediality is reliant on technologies. Chapple and Kattenbelt avoid such an assumption by recognizing both the "incorporation of digital technology" and the "presence of other media" as starting points in defining intermediality. ${ }^{87}$ Throughout their conceptual framework, they emphasize that intermediality is a phenomenon that is not reliant on technology. ${ }^{88}$

\section{CONCLUSION}

My aim in this article was to explore an intermedia research axis in African theatre from existing theory and practice that is situated in the African theatre contexts. In this undertaking, I was limited in scope and I did not set out to build an elaborate and autonomous body of theory on intermediality in African theatre. I proposed to provide the basis of conceptualizing the intermedial phenomenon as intermedial in African theatre contexts.

While most of the body of literature on theatrical intermediality has been generated in the European context, this article recognized that there are (contextual) considerations at play in designating a phenomenon as intermedial in African theatre. The article was therefore purposefully contextual: it attempted to create an understanding of intermediality in a specific geographical context outside the dominant paradigm.

I have argued that if intermediality by definition is about relations, interactions, and interferences between media, it is a very important concept for African theatre studies. In fact, discussions on media interrelations have existed at various moments in the history of African theatre, in some cases through the use of similar concepts such as interartiality, hybridity, and syncretism, and recently in the discussions on new media technologies on stage. Studies on intermediality in African theatre however, need to take into account the historical and sociopolitical factors of the specific African contexts. This approach is attentive to the fact that writing about intermediality in Africa is not only closely connected to the artistic, material, and media-related phenomenon, but also to the context of production of meaning that grows from these actions for a particular historical audience. Discounting the interrelations between old media forms and new media technologies is not reflective of the realities on the ground in this new digital era.

\footnotetext{
87 Chapple and Kattenbelt, 2006, p. II.
}

$88 \mathrm{Ibid}$. p. I2, 2I. 
I50 Unsurprisingly, there are diverse sorts of media interrelations manifest in the examples of contemporary theatre from specific contexts that have been presented in this article (Malawi and South Africa). These examples confirm that it has simply become impossible to view the theatre in these contexts and new media technologies as isolated and contrasting entities.

Borrowing a leaf from Rustom Bharucha's 89 approach towards interculturalism, I believe that if research on African theatre pursues an intermedia research axis, there is a need to contextualize such research within its history, in its diversity. African theatre studies cannot assume that a Western perspective on intermediality is applicable to the African theatre contexts. No theory or critique of intermediality can be created without confronting the politics of its location.

${ }^{89}$ Rustom Bharucha, Theatre and the World: Performance and the Politics of Culture, New York, Routledge, 2005. 


\title{
The Politics of Intermediality in African Theatre Contexts
}

\author{
Catherine Makhumula, University of Malawi
}

\section{ABSTRACT}

In this article, I discuss the politics of intermediality in African theatre contexts. My underlying assumption is that the study of intermediality is inevitably contextual in nature because intermediality is strongly linked to the sociopolitical and economic context. Jens Schröter explores the links between intermediality and ideological/politico-economic factors in his article "The Politics of Intermediality." $\mathrm{He}$ argues that questions concerning intermediality are by no means purely theoretical or aesthetic questions; rather, they are laden with political connotations. Following Schröter, my approach emphasizes how different cultures understand media differences and their interaction in a given historical phase. Using examples from the Southern region of the African continent, this article navigates through divergent theories of African theatre in its attempt to understand how media interrelations are conceptualized within the theoretical discourses in the region.

\section{RÉSUMÉ}

Dans cet article, nous discutons de la politique de l'intermédialité saisie dans le contexte du théâtre africain. Notre hypothèse est que l'étude de l'intermédialité est de nature inévitablement contextuelle en étant fortement liée aux sphères sociopolitique et économique. Dans son article «The Politics of Intermediality », Jean Schröter explore les liens entre l'intermédialité et les facteurs idéologiques / politicoéconomiques, soutenant que les questions relatives à l'intermédialité ne sont jamais exclusivement théoriques ou esthétiques, mais au contraire chargées de connotations politiques. S'appuyant sur ce dernier, notre approche se focalise sur la façon dont une culture développe sa compréhension propre des interactions et des différences entre les médias, à un moment historique donné. En utilisant des exemples provenant de la région sud du continent africain, cet article parcourt des théories divergentes sur le théâtre en Afrique, afin de mieux comprendre les relations entre les médias, telles que le discours théorique propre à cette région les conceptualise.

\section{NOTE BIOGRAPHIQUE}

Catherine Makhumula is currently a lecturer in theatre arts in the Department of Fine and Performing Arts at Chancellor College of the University of Malawi. She has recently obtained her PhD in Drama and Theatre Studies at Stellenbosch University. 
She holds an MA in International Performance Research from the University of Warwick, UK and the University of Amsterdam in the Netherlands. Catherine's research interests include intermediality in theatre, Theatre for Development, and creative activism. 